\title{
Seasonal and spatial variation of bacterial production in the continental shelf of the East China Sea: possible controlling mechanisms and potential roles in carbon cycling
}

\author{
Fuh-Kwo Shiah $^{\mathrm{a}, \mathrm{b}, *}$, Gwo-Ching Gong ${ }^{\mathrm{c}}$, Chung-Chi Chen ${ }^{\mathrm{b}, \mathrm{d}}$ \\ ${ }^{a}$ Institute of Oceanography, National Taiwan University, P.O. Box 23-13, Taipei, Taiwan \\ ${ }^{\mathrm{b}}$ National Center for Ocean Research, Taipei, Taiwan \\ ${ }^{\mathrm{c}}$ Department of Oceanography, National Taiwan Ocean University, Keeloung, Taiwan \\ ${ }^{\mathrm{d}}$ Department of Biology, National Taiwan Normal University, Taipei, Taiwan
}

Accepted 10 December 2002

\begin{abstract}
Surveys of bacterial biomass (38-673 $\mathrm{mg} \mathrm{C} \mathrm{m}^{-2}$ ), bacterial production $\left(6-179 \mathrm{mg} \mathrm{C} \mathrm{m}^{-2} \mathrm{~d}^{-1}\right)$, primary production (17-2079 $\mathrm{mg} \mathrm{C} \mathrm{m}^{-2} \mathrm{~d}^{-1}$ ) as well as other hydrographic variables within the mixed layer or euphotic zone were conducted in the East China Sea (ECS) shelf in December 1997 and March 1998 (cold seasons; SST, 10-26 ${ }^{\circ}$ C) as well as June and October 1998 (warm seasons; SST, 21-30 ${ }^{\circ} \mathrm{C}$ ). The results showed that bacterial rate parameters and biomass were regulated independently. Substrate supply and temperature might be the two most important factors interactively affecting the spatial and seasonal patterns of bacterial rate parameters. However, their relative importance shifted with season and location. During warm seasons, when SST was high $\left(>20^{\circ} \mathrm{C}\right)$, integrated bacterial productivity (IBP; 9-179 $\mathrm{mg} \mathrm{C} \mathrm{m}^{-2} \mathrm{~d}^{-1}$ ) and turnover rate $\left(\mathrm{B} \mu ; 0.03-0.37 \mathrm{~d}^{-1}\right)$ over the entire shelf were dominated by substrate supply, as judged from their positive relationships with integrated primary productivity (IPP; $18-2079 \mathrm{mg} \mathrm{C} \mathrm{m}^{-2} \mathrm{~d}^{-1}$ ). Multiple regression analysis indicated that during cold seasons, spatial variations of IBP $\left(6-59 \mathrm{mg} \mathrm{Cm}^{-2} \mathrm{~d}^{-1}\right)$ and $\mathrm{B} \mu$ $\left(0.06-0.23 \mathrm{~d}^{-1}\right)$ were explained better by temperature inside, and substrate supply outside, the middle-shelf. Annual average of IBP:IPP ratio was $17 \pm 13 \%$, which is close to the global average of $25 \%$. Bacterial carbon demand (BCD) estimated by two independent approaches yielded similar values of 430 and $482 \mathrm{mg} \mathrm{Cm}^{-2} \mathrm{~d}^{-1}$. This implies that bacteria might consume organic carbon equivalent to seasonal averaged IPP (370 $\mathrm{mg} \mathrm{C} \mathrm{m}^{-2} \mathrm{~d}^{-1}$; Gong et al., 2003). Substrate sources from non-algal components plays an important role in supporting BCD in the ECS shelf. For all four seasons, IBP:IPP ratios (6-86\%) were negatively correlated with IPP, suggesting a greater response of phytoplankton to inorganic nutrient inputs than that of bacteria to organic substrate supply. Possible mechanisms and implications are considered.
\end{abstract}

(C) 2003 Elsevier Science Ltd. All rights reserved.

\footnotetext{
*Corresponding author. Institute of Oceanography, National Taiwan University, P.O. Box 23-13, Taipei, Taiwan. Tel./fax: +886-2-2369-5746.

E-mail address: fkshiah@ccms.ntu.edu.tw (F.-K. Shiah).
}

\section{Introduction}

Heterotrophic bacterioplankton (bacteria) are the organisms primarily responsible for the utilization of dissolved organic carbon (DOC) in aquatic 
ecosystems. Many studies (Carlson et al., 1994; Hansell and Carlson, 1998) have demonstrated that bacterial activity has profound effects on local and global cycling of $\mathrm{CO}_{2}$ due to the bacterial consumption capacity on DOC, which constitutes more than $95 \%$ of the total organic carbon pool in the ocean. Several researches (Findlay et al., 1991; Smith and Hollibaugh, 1993; Biscay et al., 1994; Del Giorgio et al., 1997) have suggested that the high productivity coastal and shelf ecosystems might be a net $\mathrm{CO}_{2}$ source due to high bacterial production (BP), although this issue is still under debate.

Since the proposal of the microbial loop concept (Pomeroy, 1974; Williams, 1981; Azam et al., 1983), the mechanisms regulating temporal and spatial variability of $\mathrm{BP}$, biomass and turnover rate has been one of the central issues of modern microbial ecology study. Several controlling processes including organic substrate supply (bottomup control), bacterivory (top-down control), viral lysis and physical (temperature) forcing have been proposed (for review see Ducklow and Carlson, 1992; Fuhrman, 1992). It is suspected that the controlling processes on biomass and turnover rate might be dissimilar (Ducklow, 1999) and the relative importance of various controlling factors in regulating bacterial growth might change with time (seasons) and location. Complete and consistent data sets are essential to examine this issue.

Ducklow (1999) examined BP and primary production (PP) data derived from seven oceanic provinces and found that their ratio (BP:PP ratios) was usually below $25 \%$ and that the CV (coefficient of variation) values of $\mathrm{BP}$ and $\mathrm{PP}$ within system were very similar. These facts suggested that in the open ocean, phytoplankton productivity was the ultimate source for bacterial growth. However, analyses of data derived from coastal and shelf systems with strong physical, hydrographical and biological gradients to date have been few (Cole et al., 1988; White et al., 1991; Sanders et al., 1992). Therefore, study of the spatial and temporal variation of BP, PP and their ratio in shelf systems might give indications of the shifting among different controlling processes on $\mathrm{BP}$ and possibly, the characteristics of a system that might tend toward autotrophic or heterotrophic status (Del Giorgio et al., 1997).

The East China Sea (ECS) is one of the largest shelves in the world. Four different water masses have been identified that affect the hydrography of the ECS. They are the nutrient-laden China Coastal Waters (the CCW) with strong seasonal variation of temperature and salinity, the warm oligotrophic Taiwan Strait Waters (the TSW), the cool upwelled Kuroshio Subsurface Waters (the KSW) and the warm oligotrophic Kuroshio Waters (the KW). The CCW and the KSW serve as the two major inorganic nutrient sources in the ECS shelf. Recent studies have shown that the physical, hydrographical and biological features in the ECS include strong gradients that change dramatically with seasons (Wong et al., 2000; Gong et al., 1996, 2000; Gong et al., 2003). We believe that the complicated hydrography caused by the seasonal interactions of different water types in the shelf area might ultimately affect the temporal and spatial patterns of algal biomass and productivity and thus bacterial activity.

The major purpose of this study was to understand temporal and spatial patterns of bacterial biomass, production and turnover rate in the shelf area of the ECS. Bacterial relationships with PP and other hydrography data were analyzed to test the hypothesis that the processes controlling bacterial growth might shift between seasons and locations. Bacterial carbon demand (BCD) (consumption) and its potential role in carbon cycling in the ECS shelf also are discussed.

\section{Materials and methods}

\subsection{Study area and sampling}

This study was performed in the shelf of the ECS north of Taiwan (Fig. 1; 25-32 $\mathrm{N}$; $\left.120-127^{\circ} \mathrm{E}\right)$. A total of four cruises were conducted in winter 1997 (December 19-29), spring 1998 (March 16-26), summer 1998 (June 28-July 06) and autumn 1998 (October 29-November 06). 
Seawater was collected from a SeaBird CTDGeneral Oceanic Rosette assembly with 20-1 Go-Flo bottles. Light intensity was measured with a PAR sensor (QSP200L; Biospherical Inc.) and the depth of the euphotic-zone was defined as $1 \%$ of the surface light penetrated. All measurements described below were conducted with samples taken from the same cast.

\subsection{Primary productivity, chlorophyll-a and nitrate concentration}

Chlorophyll- $a$ and nitrate concentrations were measured following the methods of Parsons et al. (1984). PP was measured by the ${ }^{14} \mathrm{C}$ assimilation method (Parsons et al., 1984). Integrated values of PP (IPP), chlorophyll and nitrate concentrations $\left(\mathrm{IChl}, \mathrm{INO}_{3}\right)$ were obtained by integrating (trapezoidal method) over the euphotic zone $\left(Z_{\mathrm{e}}\right)$. For detail, see Gong et al. (2003).

\subsection{Bacterial abundance and production and statistical analysis}

Bacterial abundance was determined by using the acrindine orange direct count method (Hobbie et al., 1977). Biomass was calculated with a carbon conversion factor (TCF) of $2 \times 10^{-14} \mathrm{~g} \mathrm{cell}^{-1}$ (Lancelot and Billen, 1984). BP was estimated by ${ }^{3} \mathrm{H}$-[methyl]-thymidine (Fuhrman and Azam, 1982) incorporation (S.A., $6.7 \mathrm{Ci} \mathrm{mmol}^{-1}$; final conc., $20 \mathrm{nM}$;), with a conversion factor (TCF) of $1.18 \times 10^{18}$ cells mol thymidine ${ }^{-1}$ We adopted these conversion factors since they had been used in several previous bacterial studies conducted in this area (Shiah et al., 2000a, b, 2001). For each station, triplicate samples were taken from 7 to 11 depths within $Z_{\mathrm{e}}$. The integrated bacterial biomass (IBB) and production (IBP) were obtained by integrating (trapezoidal method) over $Z_{\mathrm{e}}$. Bacterial turnover rate $(\mathrm{B} \mu)$ was calculated by dividing IBP

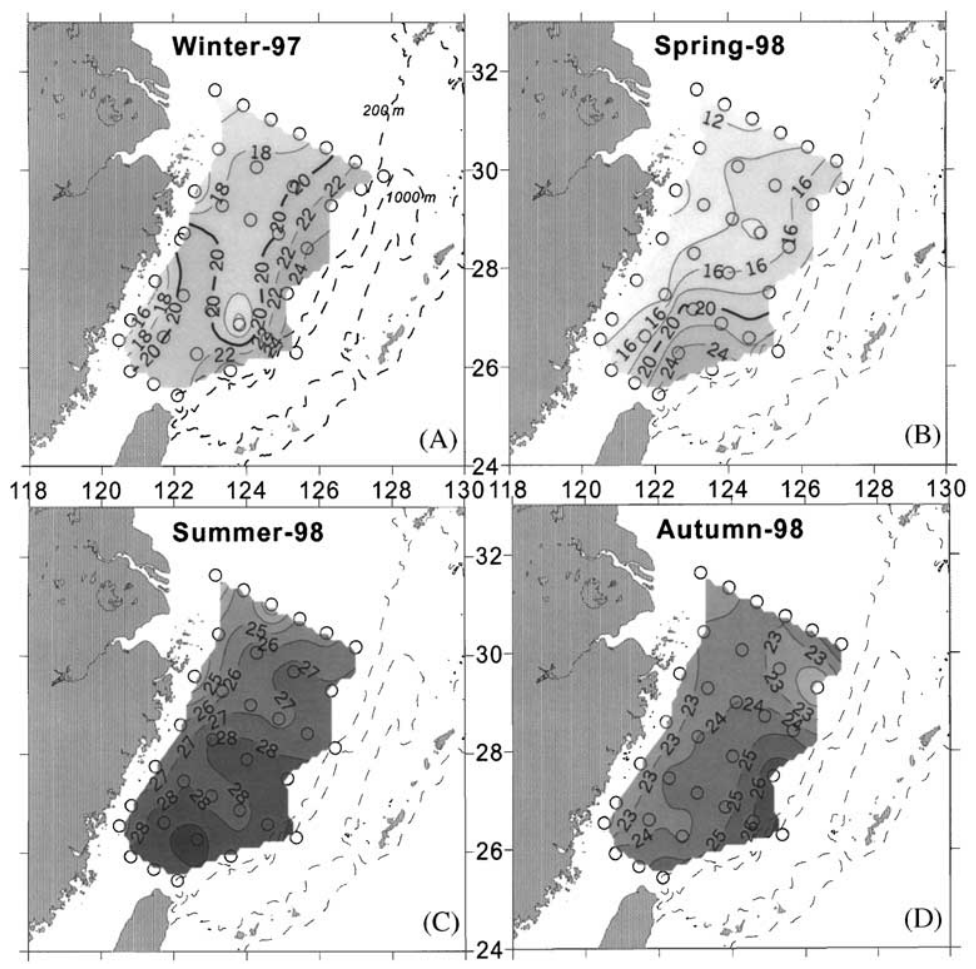

Fig. 1. Contours of sea surface temperature $(A-D)$ and salinity $(E-H)$ showing sampling stations in the ECS of the four cruises. Bold lines in $(\mathrm{A}-\mathrm{D})$ and $(\mathrm{E}-\mathrm{H})$ indicate the $20^{\circ} \mathrm{C}$ isotherms and the $33.00 \mathrm{psu}$ isohalines, respectively. Dashed lines indicate bottom depth in meters. 


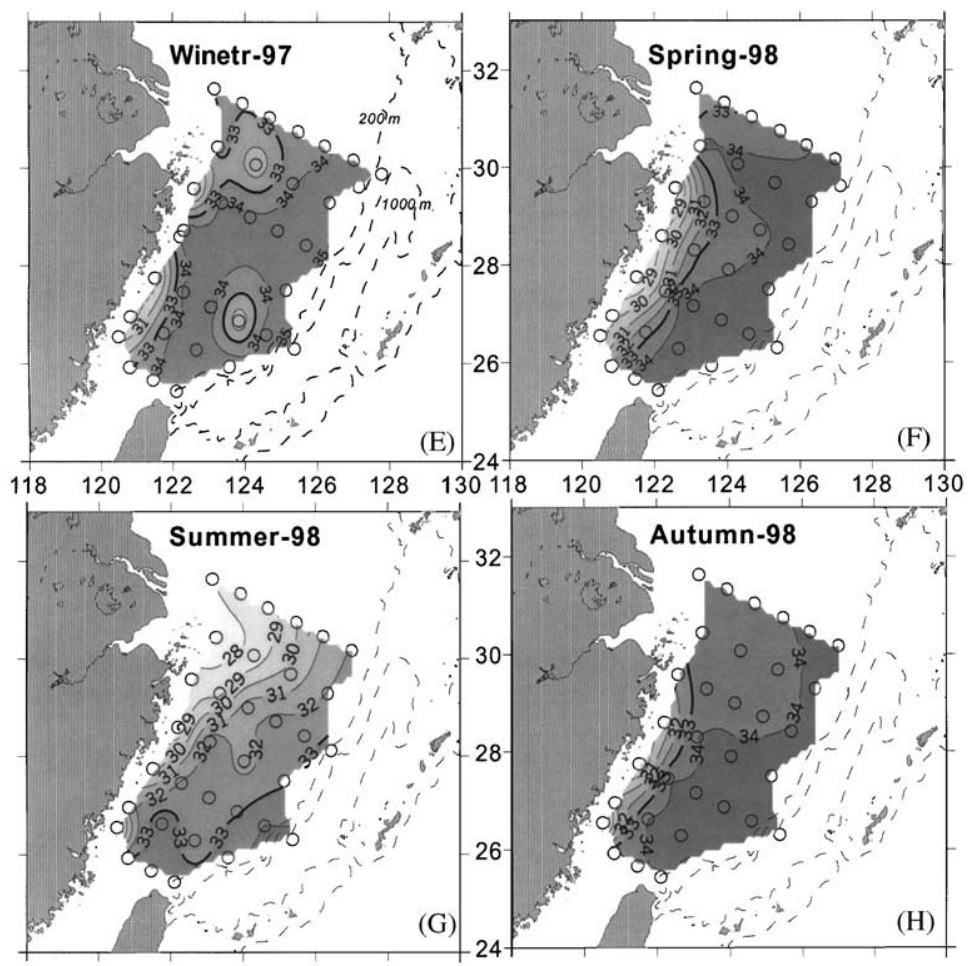

Fig. 1 (continued).

with IBB. The software StatView II ${ }^{\mathrm{TM}}$ (in Macintosh) was used for the analysis of multiple and simple linear regression (model 2), analysis of variance (ANOVA), analysis of covariance (ANCOVA) as well as multiple comparisons.

\section{Results}

\subsection{Hydrography}

The ECS shelf showed strong seasonal and spatial variation in hydrography (Table 1), particularly for areas inside the mid-shelf where water temperatures and salinities were significantly affected by seasonally varied river-water inputs from the coast of the Mainland China (Figs. 1A$\mathrm{H})$. In brief, a cold $\left(<14^{\circ} \mathrm{C}\right)$ and low-salinity $(<33.00 \mathrm{psu})$ plume was confined to area near the China coast during winter; it became even colder $\left(<12^{\circ} \mathrm{C}\right)$ in spring when the Yangtze River (aka. the ChangJiang) runoffs started to increase. During summer, this plume reached its largest size but became a warm one with temperatures $>21^{\circ} \mathrm{C}$. In autumn, the warm and low-salinity plume still existed but much smaller in size. Nitrate $\left(\mathrm{NO}_{3}\right)$ in general was high on the inner-shelf during all season and decreased seaward (Gong et al., 2003). During winter and spring, nutrientladen $(>1.0 \mu \mathrm{M})$ waters could extend to the shelfbreak of the ECS. In spite of the fact that riverwater inputs were the highest during summer, the area with $\mathrm{NO}_{3}>1.0 \mu \mathrm{M}$ was smaller than that of spring and restricted to the northeastern part of the ECS (the Yangtze River mouth); this nutrientenriched water shrank and was confined to the China coastline during autumn. Overall, temporal and spatial variations of inorganic nutrient might be a net result of river inputs (high in spring and summer, low in autumn and winter) and algal activity (low in winter and spring, reached maximum in summer and decreased during autumn; 
Table 1

List of the ranges, averages (Ave), standard deviations (std) and coefficients of variation $(\mathrm{CV}=[\mathrm{std} / \mathrm{Ave}] \times 100 \%)$ of measured variables derived from the four cruises conducted in the continental shelf of the East China Sea

\begin{tabular}{|c|c|c|c|c|c|c|c|c|c|}
\hline \multirow[t]{3}{*}{ Items } & \multirow[t]{3}{*}{ Units } & \multicolumn{8}{|l|}{ Seasons } \\
\hline & & \multicolumn{2}{|l|}{ Winter 1997} & \multicolumn{2}{|l|}{ Spring 1998} & \multicolumn{2}{|c|}{ Summer 1998} & \multicolumn{2}{|l|}{ Autumn 1998} \\
\hline & & Range & Ave \pm std CV & Range & Ave \pm std CV & Range & Ave \pm std CV & Range & Ave \pm std CV \\
\hline Surface temperature & ${ }^{\circ} \mathrm{C}$ & $13.5-26.0$ & $\begin{array}{l}19.5 \pm 3.3 \\
17 \%\end{array}$ & $11.0-26.0$ & $\begin{array}{l}16.3 \pm 4.4 \\
27 \%\end{array}$ & $20.9-29.6$ & $\begin{array}{l}26.8 \pm 2.1 \\
8 \%\end{array}$ & $20.5-27.4$ & $\begin{array}{l}23.8 \pm 1.6 \\
7 \%\end{array}$ \\
\hline Surface salinity & psu & $28.85-34.77$ & $\begin{array}{l}33.35 \pm 1.8 \\
4.5 \%\end{array}$ & $27.20-34.78$ & $\begin{array}{l}33.02 \pm 2.19 \\
6.6 \%\end{array}$ & $27.14-34.21$ & $\begin{array}{l}31.25 \pm 2.18 \\
6.9 \%\end{array}$ & $27.38-34.43$ & $\begin{array}{l}33.35 \pm 1.68 \\
5.1 \%\end{array}$ \\
\hline Surface nitrate & $\mu \mathrm{M}$ & $<0.2-20.8$ & $\begin{array}{l}5.3 \pm 6.0 \\
113 \%\end{array}$ & $<0.2-28.3$ & $\begin{array}{l}6.5 \pm 7.0 \\
108 \%\end{array}$ & $<0.2-28.1$ & $\begin{array}{l}3.9 \pm 7.0 \\
6.6 \%\end{array}$ & $<2.0-24.3$ & $\begin{array}{l}3.4 \pm 5.9 \\
173 \%\end{array}$ \\
\hline Integrated chlorophyll & $\mathrm{mg} \mathrm{Chl} \mathrm{m}{ }^{-2}$ & $2-59$ & $\begin{array}{l}26 \pm 15 \\
58 \%\end{array}$ & $1-70$ & $\begin{array}{l}25 \pm 15 \\
60 \%\end{array}$ & $14-68$ & $\begin{array}{l}29 \pm 14 \\
48 \%\end{array}$ & $2-75$ & $\begin{array}{l}35 \pm 21 \\
60 \%\end{array}$ \\
\hline Integrated prim. production (IPP) & $\mathrm{mgC} \mathrm{m} \mathrm{m}^{-2} \mathrm{~d}^{-1}$ & $17-649$ & $\begin{array}{l}276 \pm 162 \\
59 \%\end{array}$ & $25-669$ & $\begin{array}{l}269 \pm 155 \\
58 \%\end{array}$ & 149-2079 & $\begin{array}{l}572 \pm 487 \\
85 \%\end{array}$ & $18-765$ & $\begin{array}{l}362 \pm 226 \\
62 \%\end{array}$ \\
\hline Integrated bact. biomass (IBB) & $\mathrm{mg} \mathrm{C} \mathrm{m} \mathrm{m}^{-2}$ & $38-353$ & $\begin{array}{l}230 \pm 67 \\
29 \%\end{array}$ & $200-673$ & $\begin{array}{l}433 \pm 150 \\
35 \%\end{array}$ & $125-685$ & $\begin{array}{l}384 \pm 112 \\
29 \%\end{array}$ & $222-426$ & $\begin{array}{l}300 \pm 55 \\
18 \%\end{array}$ \\
\hline Integrated bact. production (IBP) & $\mathrm{mg} \mathrm{C} \mathrm{m} \mathrm{m}^{-2} \mathrm{~d}^{-1}$ & $6-53$ & $\begin{array}{l}33 \pm 13 \\
39 \%\end{array}$ & $25-59$ & $\begin{array}{l}45 \pm 9 \\
20 \%\end{array}$ & $22-179$ & $\begin{array}{l}61 \pm 36 \\
59 \%\end{array}$ & $9-70$ & $\begin{array}{l}39 \pm 17 \\
44 \%\end{array}$ \\
\hline Bact. turnover rate ${ }^{\mathrm{a}}(\mathrm{B} \mu)$ & $\mathrm{d}^{-1}$ & $0.07-0.23$ & $\begin{array}{l}0.14 \pm 0.05 \\
36 \%\end{array}$ & $0.06-0.21$ & $\begin{array}{l}0.11 \pm 0.04 \\
36 \%\end{array}$ & $0.06-0.37$ & $\begin{array}{l}0.16 \pm 0.08 \\
50 \%\end{array}$ & $0.03-0.24$ & $\begin{array}{l}0.13 \pm 0.05 \\
38 \%\end{array}$ \\
\hline IBP:IPP ratio & $\%$ & $6-37$ & $\begin{array}{l}15 \pm 7 \\
47 \%\end{array}$ & $7-86$ & $\begin{array}{l}25 \pm 21 \\
84 \%\end{array}$ & $4-36$ & $\begin{array}{l}15 \pm 8 \\
53 \%\end{array}$ & $4-57$ & $\begin{array}{l}15 \pm 10 \\
67 \%\end{array}$ \\
\hline
\end{tabular}

${ }^{\mathrm{a}} \mathrm{B} \mu=\mathrm{IBP} / \mathrm{IBB}$. 
Gong et al., 2003). Detailed descriptions of the temporal and spatial variations of the euphotic zone integrated chlorophyll concentrations (IChl) and IPP are presented in Gong et al. (2003, their Figs. 8-9).

\subsection{Variation of bacterial measurements during cold seasons}

The cold seasons' data were categorized into $<20^{\circ} \mathrm{C}$ and $>20^{\circ} \mathrm{C}$ data sets (Shiah et al., 1999), which represented the inner- and outer-shelf, respectively. Depth-integrated BP (IBP) during winter $\left(6-53 ; 33 \pm 13 \mathrm{mg} \mathrm{C} \mathrm{m}^{-2} \mathrm{~d}^{-1}\right)$ and spring $\left(25-59 ; 45 \pm 9 \mathrm{mg} \mathrm{C} \mathrm{m}^{-2} \mathrm{~d}^{-1}\right)$ were low on the innerand outer-shelf (Figs. 2A and B, Table 1). Below the $20^{\circ} \mathrm{C}$ isotherm (areas inside the mid-self), IBP was higher in spring than in winter (Fig. 5A). Depth-IBB during winter $(38-353 ; 230 \pm 67 \mathrm{mg}$ $\mathrm{C} \mathrm{m}^{-2}$ ) showed no spatial pattern (Fig. 3A). While values of spring IBB (200-673; 433 $\pm 150 \mathrm{mg}$ $\mathrm{C} \mathrm{m}^{-2}$ ) were high on the inner-shelf, then decreased offshore and then remained more or less constant outside the mid-shelf (Fig. 3B). Bacterial turnover rates $(\mathrm{B} \mu=\mathrm{IBP} / \mathrm{IBB})$ of the 2 cruises showed similar patterns with IBP. Values of $\mathrm{B} \mu$ were low $\left(0.06-<0.10 \mathrm{~d}^{-1}\right)$ on the innershelf, peaked on the mid-shelf $\left(0.16-0.24 \mathrm{~d}^{-1}\right)$ along the $20^{\circ} \mathrm{C}$ isotherm, and then decreased to values ca. $0.08 \mathrm{~d}^{-1}$ on the outer-shelf areas (Figs. 4A, B, and 5B).

Bacterial relationships with temperature $(T)$ and IPP were analyzed by multiple regression analysis. For areas with $T<20^{\circ} \mathrm{C}$, IBP and $\mathrm{B} \mu$ were more strongly correlated with $T$ than with IPP (Table 2; Figs. 5A and B). Note that the intercepts and slopes for IBP vs. $T$ from both cruises were different from each other (ANCOVA, $p<0.01$ ). This could be ascribed to the different IBB during winter and spring (Figs. 2A and B). Meanwhile, the intercepts and slopes for $\mathrm{B} \mu$ vs. $T$ from both cruises were quite consistent (ANCOVA, $p>0.01$ ). This indicated that temperature might be more important than local substrate supply in regulating

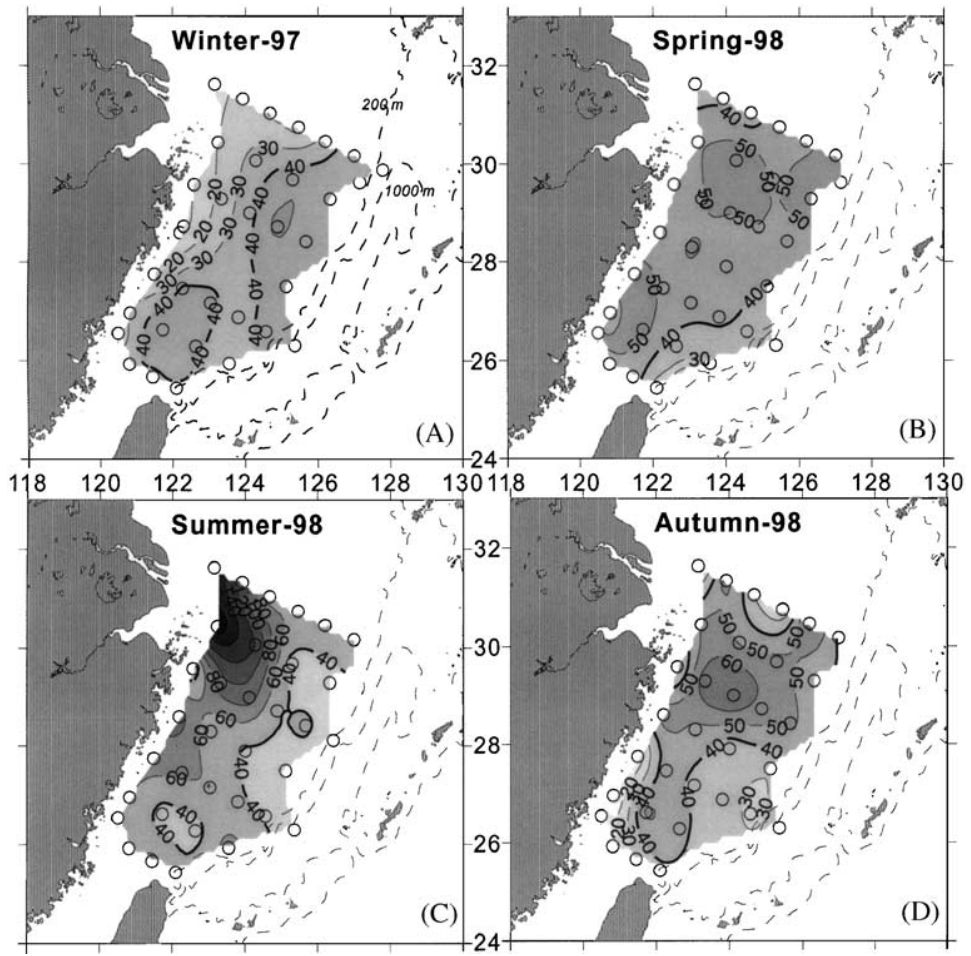

Fig. 2. The same as Fig. 1 but for euphotic zone IBP in unit of $\mathrm{mg} \mathrm{Cm}^{-2} \mathrm{~d}^{-1}$. Bold lines indicate the $40 \mathrm{mg} \mathrm{C} \mathrm{m}^{-2} \mathrm{~d}^{-1}$ isolines. 


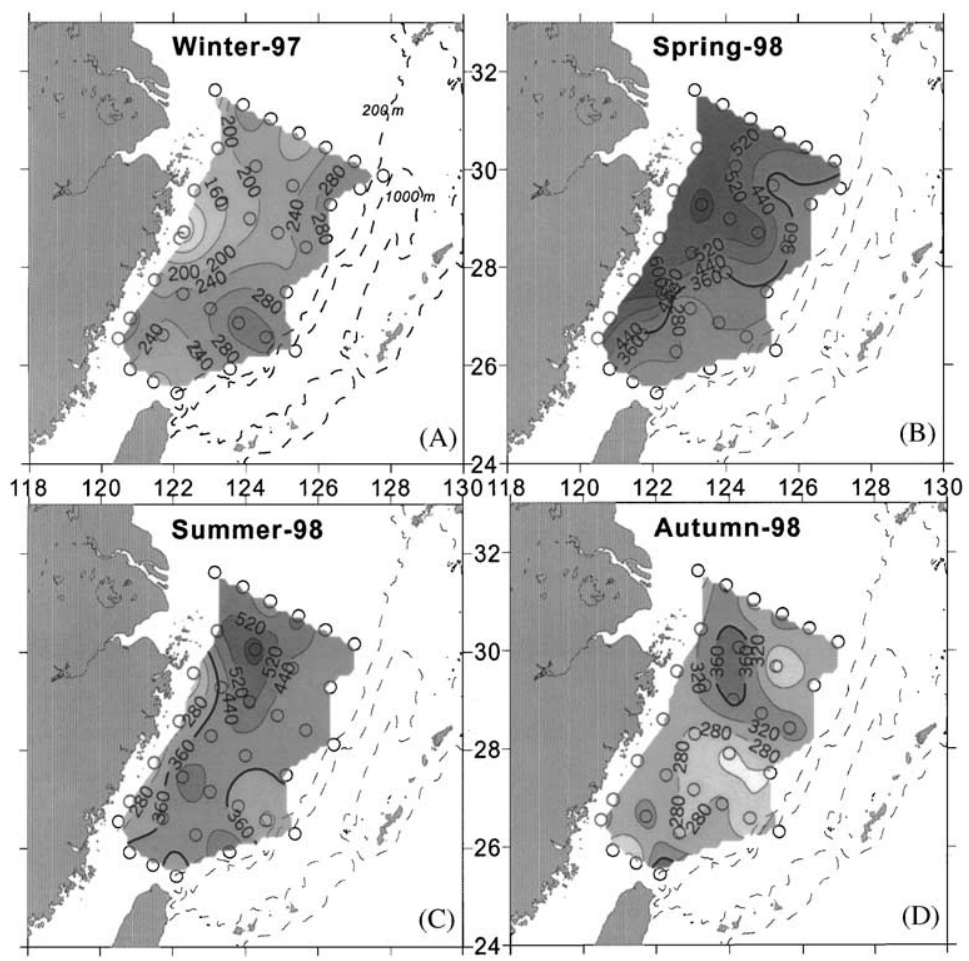

Fig. 3. Same as Fig. 2 but for euphotic zone IBB in unit of $\mathrm{mg} \mathrm{Cm}^{-2}$. Bold lines indicate the $360 \mathrm{mg} \mathrm{Cm}^{-2}$ isolines.

the spatial variability of IBP and $\mathrm{B} \mu$ inside the mid-shelf in winter and spring. Note also that on the outer-shelf (areas with $T>20^{\circ} \mathrm{C}$ ), IBP and $\mathrm{B} \mu$ of both cruises were positively correlated with IPP (Table 2; Figs. 6A and B; $r>+0.84, n=12$, $p<0.01)$. This suggested that substrate supply could be more crucial in affecting bacterial growth outside the mid-shelf during cold seasons. Winter and spring IBB were positively and negatively correlated with IPP and $T$ (and salinity, data not shown), respectively (Table $2, p<0.01$ ) inside the mid-shelf. There was no correlation for IBB vs. IPP or IBB vs. $T$ outside the mid-shelf.

\subsection{Variation of bacterial measurements during warm seasons}

Values of IBP (Figs. 2C and D; 22-179 mg $\mathrm{C} \mathrm{m}^{-2} \mathrm{~d}^{-1}$ ), IBB (Figs. 3C and D; 125-685 mg $\mathrm{C} \mathrm{m}^{-2}$ ) and $\mathrm{B} \mu$ (Figs. $4 \mathrm{C}$ and $\mathrm{D} ; 0.06-0.37 \mathrm{~d}^{-1}$ ) of summer were ca. $30 \%$ (Table 1 ) higher than those of autumn (222-426 mg C m${ }^{-2}, 9-70 \mathrm{mg} \mathrm{C} \mathrm{m}^{-2} \mathrm{~d}^{-1}$ and $0.03-0.24 \mathrm{~d}^{-1}$ ). For both seasons, IBB values were higher and formed dome-shaped patterns outside the Yangtze River mouth, and then decreased seawards. IBP of summer and autumn showed distinct spatial patterns. In summer, IBP were high on the inner-shelf and then decreased seawards; while in autumn, IBP peaked on the mid-shelf with lower values on the inner- and outer-shelf. Spatial distribution of $\mathrm{B} \mu$ (Figs. 4C and D) for summer and autumn followed the same patterns as IBP.

There were no significant relationships for IBB vs. IPP and IBB vs. $T$ (Table 2 ) on either cruise. However, bacterial rate parameters (IBP and $\mathrm{B} \mu$ ) were positively correlated with IPP (Table 2; Figs. 6A and B). The intercepts and slopes of $\mathrm{B} \mu$ on IPP of summer and autumn were similar (ANCOVA, $p>0.01$ ). Positive correlations also were observed for IBP vs. IChl $(r>+0.66, n=32$, $34, p<0.01)$ and $\mathrm{B} \mu$ vs. IChl $(r>+0.75, n=32$, $34, p<0.01)$ for both seasons. All these facts suggested that during warm seasons, bacterial 


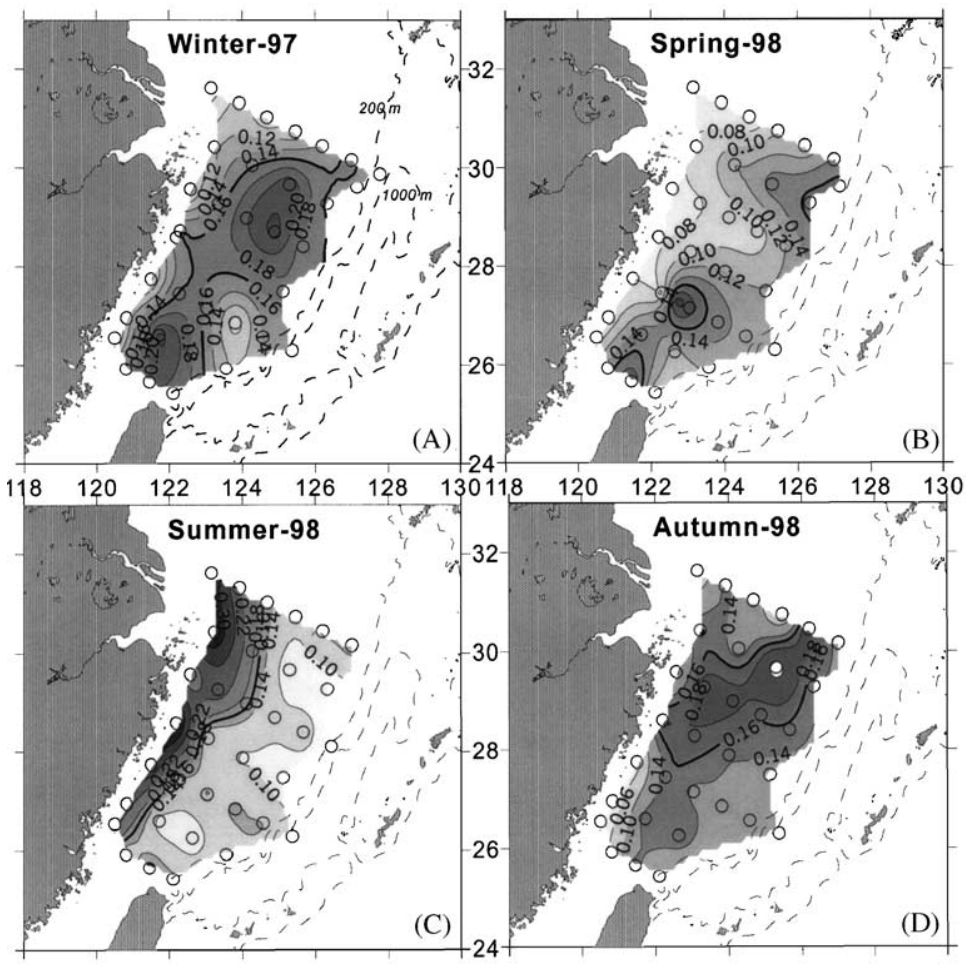

Fig. 4. Same as Fig. 2 but for bacterial turnover rates $(B \mu=I B P / I B B)$ in unit of $\mathrm{d}^{-1}$. Bold lines indicate the $0.16 \mathrm{~d}^{-1}$ isolines.

growth over the entire shelf might be more affected by substrate supply (IPP) when growth temperatures were high $\left(>20^{\circ} \mathrm{C}\right)$

\subsection{Temporal and spatial variations of IBP:IPP ratios}

Variation of IPP (Table $1, \mathrm{CV}=58-85 \%$ ) was greater than that of IBP $(\mathrm{CV}=20-59 \%)$ and the greatest $\mathrm{CV}$ values for IPP, IBP and $\mathrm{B} \mu$ $(\mathrm{CV}=50 \%)$ all occurred in summer while IChl was the least variable $(\mathrm{CV}=48 \%)$. These facts suggested that values and variations of biological activities (not necessarily standing stocks) in the ECS shelf were the highest during summer. The ratios of IBP:IPP for the four cruises ranged 4$86 \%$ (Table 1), with seasonal averages of $15 \pm 7 \%$, $25 \pm 21 \%, \quad 15 \pm 8 \%$ and $15 \pm 10 \%$ for winter, spring, summer and autumn, respectively. The grand average was $17 \pm 13 \%$. Multiple comparison analysis showed that there was no difference among seasonal averages of IBP:IPP ratio $(p>0.01)$. When plotted with IPP, these ratios decreased as IPP increased (Fig. 7A, $p<0.01$ ) for all four seasons. The intercepts and slopes of IBP:IPP ratios on IPP were not significantly different from one another except spring (Table 3, ANCOVA). Further analysis showed that the ratios were negatively correlated with phytoplankton biomass (IChl, Fig. 7B) but not with algal turnover rate (IPP/IChl), indicating that the latter seemed to be less effective in affecting the variation of IBP:IPP ratios with the exception of summer data.

\section{Discussions and conclusions}

\subsection{Mechanisms affecting bacterial growth}

Significant spatial and seasonal contrasts in physical, chemical and biological variables 

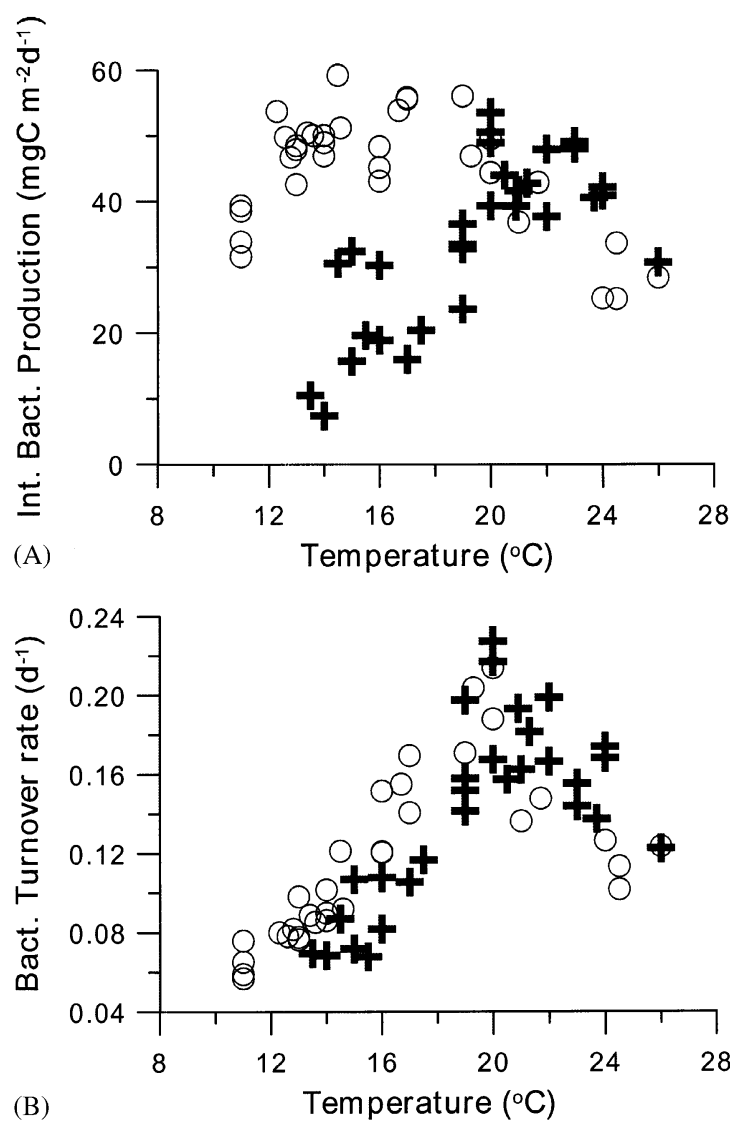

Fig. 5. Plots of IBP (A) and $\mathrm{B} \mu(\mathrm{B})$ vs. water temperature with the data of winter 1997 (crosses) and spring 1998 (circles).

made the ECS shelf an ideal natural laboratory for examining the relationships between environmental factors and bacterial rate parameters (turnover rate and production). BP is a product of biomass and turnover rate $(\mathrm{IBP}=\mathrm{IBB} \times \mathrm{B} \mu)$, but the factors that regulate bacterial biomass (e.g., bacterivory, viral lysis) and rate parameters (e.g., temperature, substrate supply) might be different and should be examined separately. It is admitted that the data collected from this study probably were not sufficient for analyzing some of the processes controlling bacterial biomass (e.g., bacterivory and viral lysis). In the following sections, we concentrated on processes (substrate supply and temperature) that might have impacts on bacterial rate parameters.

\subsection{Substrate supply effect of bacterial growth}

Our results showed that IBP, particularly $\mathrm{B} \mu$, over the entire shelf during warm seasons and outside the mid-shelf during cold seasons might be primarily regulated by substrate supply (Table 2). Our study further indicated that such bottom-up control on IBP was more via its regulation on $\mathrm{B} \mu$ than on IBB since no correlations were observed between IBB and IPP. This is consistent with Ducklow's (1999) conclusion that the processes regulated bacterial rate parameters and biomass might be independent. In addition, bottom-up control was effectual only when growth temperature was $>20^{\circ} \mathrm{C}$, at least this seemed to be the case in a temperate-to-subtropical ecosystem like the ECS shelf.

\subsection{Temperature effect on bacterial growth}

The cold seasons data showed that inside the mid-shelf (area with $T<20^{\circ} \mathrm{C}$ ), bacterial rate parameters increased with rising temperatures (Table 2; Figs. 5A and B). As suggested by Bott (1975), Autio (1992), Hoch and Kirchman (1993) and Shiah et al. (1999) and (other citations therein), this phenomenon occurred only under conditions when substrate supply was not limiting. From the perspective of thermodynamics, it is well known that higher temperatures can facilitate bacterial metabolism (growth) by lowering down the activation energy required for biochemical (enzymatic) reactions. Without proper (or optimal) temperature, bacteria will not grow even when organic substrate supply is in surplus. This has been demonstrated by several studies showing that bacterial growth could be significantly inhibited by low temperatures even when grown under substrate-enriched conditions (Hollibaugh, 1979; Kirchman et al., 1993; Wiebe et al., 1992, 1993; Berman et al., 1994; Shiah et al., 2000c).

\subsection{The switch between substrate and temperature effects}

The relative importance of substrate supply and temperature effects on bacterial growth might be system (or season) dependent. Our data 
Table 2

Multiple regression analysis of IBB, IBP and B $\mu$ on temperature $(T)$ and IPP (independent variables)

\begin{tabular}{|c|c|c|c|c|c|c|}
\hline \multirow[t]{2}{*}{ Categories } & \multirow[t]{2}{*}{$n$} & \multirow{2}{*}{$\begin{array}{l}\text { Dependent }^{\mathrm{a}} \\
\text { variables }\end{array}$} & \multirow{2}{*}{$\begin{array}{l}T \text { only } \\
R^{2}\end{array}$} & \multirow{2}{*}{$\begin{array}{l}\mathrm{IPP}^{\mathrm{a}} \text { only } \\
R^{2}\end{array}$} & \multirow{2}{*}{$\begin{array}{l}T+\text { IPP } \\
R^{2}\end{array}$} & \multirow[t]{2}{*}{ Best equation $^{\mathrm{b}}$} \\
\hline & & & & & & \\
\hline Winter $1997<20^{\circ} \mathrm{C}$ data & 24 & $\begin{array}{l}\text { IBB } \\
\text { IBP } \\
\mathrm{B} \mu\end{array}$ & $\begin{array}{l}\text { ns } \\
0.61 \\
0.84\end{array}$ & $\begin{array}{l}0.34 \\
0.58 \\
0.32\end{array}$ & $\begin{array}{l}0.46 \\
0.65 \\
0.84\end{array}$ & $\begin{array}{l}\log \mathrm{IBB}=-1.2+1.5( \pm 0.5) \log \mathrm{IPP} \\
\log \mathrm{IBP}=0.12+0.07( \pm 0.01) T \\
\log \mathrm{B} \mu=-2.12+0.07( \pm 0.01) T^{*}\end{array}$ \\
\hline Spring 1998 & 26 & $\begin{array}{l}\text { IBB } \\
\text { IBP } \\
\mathrm{B} \mu\end{array}$ & $\begin{array}{l}0.83 \\
0.43 \\
0.93\end{array}$ & $\begin{array}{l}\mathrm{ns} \\
0.28 \\
0.24\end{array}$ & $\begin{array}{l}\text { ns } \\
0.52 \\
0.96\end{array}$ & $\begin{array}{l}\log \mathrm{IBB}=3.34-0.05( \pm 0.01) T \\
\log \mathrm{IBP}=1.36+0.03( \pm 0.01) T \\
\log \mathrm{B} \mu=-1.79+0.06( \pm 0.01) T^{*}\end{array}$ \\
\hline Winter $1997+$ spring $1998>20^{\circ} \mathrm{C}$ data & 16 & $\begin{array}{l}\text { IBB } \\
\text { IBP } \\
\text { B } \mu\end{array}$ & $\begin{array}{l}\text { ns } \\
\text { ns } \\
\text { ns }\end{array}$ & $\begin{array}{l}\mathrm{ns} \\
0.75 \\
0.70\end{array}$ & $\begin{array}{l}\mathrm{ns} \\
0.85 \\
0.81\end{array}$ & $\begin{array}{l}\log \mathrm{IBP}=-0.90+1.00( \pm 0.24) \log \text { IPP } \\
\log \mathrm{B} \mu=-3.05+0.90( \pm 0.25) \log \mathrm{IPP}\end{array}$ \\
\hline Summer 1998 , all data & 32 & $\begin{array}{l}\text { IBB } \\
\text { IBP } \\
\text { B } \mu\end{array}$ & $\begin{array}{l}\text { ns } \\
\text { ns } \\
\text { ns }\end{array}$ & $\begin{array}{l}\mathrm{ns} \\
0.42 \\
0.69\end{array}$ & $\begin{array}{l}\text { ns } \\
0.45 \\
0.72\end{array}$ & $\begin{array}{l}\log \mathrm{IBP}=0.60+0.44( \pm 0.09) \log \mathrm{IPP} \\
\log \mathrm{B} \mu=-2.21+0.52( \pm 0.06) \log \mathrm{IPP} *\end{array}$ \\
\hline Autumn 1998 all data & 34 & $\begin{array}{l}\text { IBB } \\
\text { IBP } \\
B \mu\end{array}$ & $\begin{array}{l}\text { ns } \\
\text { ns } \\
\text { ns }\end{array}$ & $\begin{array}{l}\mathrm{ns} \\
0.72 \\
0.70\end{array}$ & $\begin{array}{l}\text { ns } \\
0.73 \\
0.75\end{array}$ & $\begin{array}{l}\log \mathrm{IBP}=0.26+0.52( \pm 0.06) \log \mathrm{IPP} \\
\log \mathrm{B} \mu=-2.14+0.49( \pm 0.06) \log \mathrm{IPP} * *\end{array}$ \\
\hline
\end{tabular}

demonstrated that bacterial growth (turnover rate) inside the mid-shelf might be temperature dominated during cold seasons and then switched to substrate supply dominated during warms seasons. This phenomenon probably is not unusual in many aquatic ecosystems (White et al., 1991; Shiah et al., 1999, 2000a, and citations therein). Ducklow (1992) suggested that the change in temperature might influence the strength of bottom-up control. From the results of a spring on-deck substrate enrichment experiments (15 dissolved free amino acids mixture, DFAA; final concs. $0.5 \mu \mathrm{M}$ ), Shiah et al. (2000c) found that when incubated at low $\left(5^{\circ} \mathrm{C}\right.$ and $10^{\circ} \mathrm{C}$ ) temperature, it took $>20 \mathrm{~h}$ (lag period) for inner-shelf bacteria to respond to the addition of DFAA; as the incubation temperature increased to $20^{\circ} \mathrm{C}$, the lag period was shortened significantly to $<2 \mathrm{~h}$. The same phenomenon was observed in DFAA-enrichment experiments conducted in summer, 1998 (Shiah et al., 2000b). These results gave direct evidence supporting
Ducklow (1992) and our conclusions. That is, the dominance of temperature and substrate controls of bacterial growth inside the ECS middle-shelf shifted between seasons.

\subsection{Regulation of IBP:IPP ratio}

From carbon cycling point of view, IPP and IBP could be viewed as the major $\mathrm{CO} 2$ sink and source processes, respectively. The changes of IBP:IPP ratio might affect the efficiency of biological pump and/or planktonic tropho-dynamics processes. Conan et al. (1999) suggested that a high BP:PP ratio might lead to a less material available for higher trophic level and/or for export to the deep ocean.

The negative relationship between IBP:IPP ratio and IPP (Table 3) has been reported by several studies (Conan et al., 1999, and citations therein), and several possible mechanisms leading to this phenomenon have been proposed by Lochte et al. 


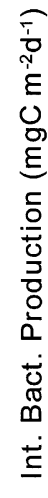

(A)

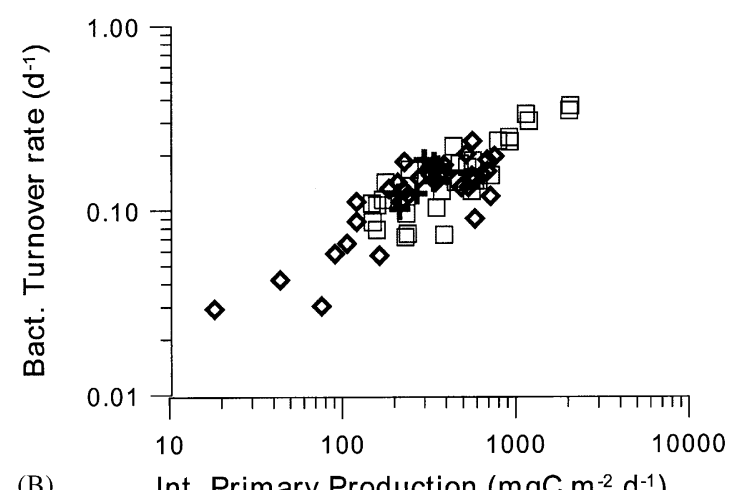

(B)

Fig. 6. Plots of IBP (A) and B $\mu$ (B) vs. euphotic zone integrated PP (IPP) with the data of summer 1998 (squares) and autumn 1998 (diamonds). Outer-shelf data of winter 1997 and spring 1998 are indicated by crosses. Note $x$ - and $y$-axis are in $\log _{10}$ scales.

(1997). Conan et al. (1999) argued that when algal turnover rate was high, phytoplankton were efficient in carbon production either through direct $\mathrm{DOC}_{\text {exud }}$ release or other autochthonous sources, a lower percent $(<25 \%)$ of IPP was sufficient to support bacterial growth, which then resulted in low IBP:IPP ratio. That is, BP was more or less saturated by abundant substrate supply when PE had reached to certain value $(>1.0 \mathrm{~g} \mathrm{Cg}$ $\left.\mathrm{Chl}^{-1} \mathrm{~h}^{-1}\right)$.

Our analysis indicated that phytoplankton effects on IBP:IPP ratio might go through either algal biomass and/or turnover rate, and such control might shift seasonally. Note that the IPP/
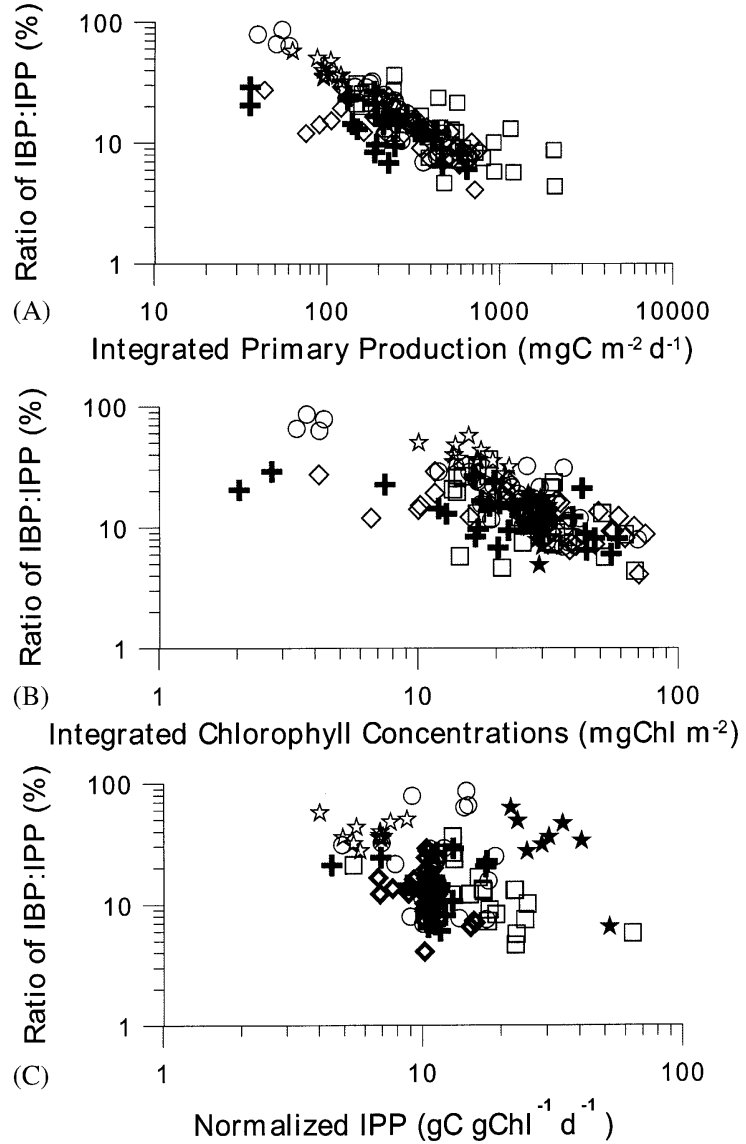

Fig. 7. Plots of the IBP:IPP ratio vs. IPP (A), IChl (B) and IPP/ IChl (C) with data of winter 1997 (crosses), spring 1998 (circles), summer 1998 (squares) and autumn 1998 (diamonds). Open and solid stars indicated normal and typhoon data (Shiah et al., 2000c), respectively. Note $x$ - and $y$-axis are in $\log _{10}$ scales.

IChl of summer varied more than 10 -fold (5-64 g $\mathrm{Cg} \mathrm{Chl}{ }^{-1} \mathrm{~d}^{-1}$ ) with a high average of $20 \mathrm{~g} \mathrm{Cg}$ $\mathrm{Chl}^{-1} \mathrm{~d}^{-1}$, while the averages of the other three seasons were lower $\left(10-11 \mathrm{~g} \mathrm{Cg} \mathrm{Chl}^{-1} \mathrm{~d}^{-1}\right)$ and with most of the IBP:IPP values falling within a narrow range of 4-19 $\mathrm{g} \mathrm{C} \mathrm{g} \mathrm{Ch}^{-1} \mathrm{~d}^{-1}$ (Fig. 7C). In fact, the spatial variation of summer IPP was determined almost equally by the changes of algal turnover rate and algal biomass, while those of the other three seasons were governed primarily by the change of algal biomass but not turnover rate (Gong et al., 2003).

We suspected that algal turnover rate effect on IBP:IPP ratio might occur only when IPP/IChl 
Table 3

Linear regression analysis for the IBP:IPP ratio (dependent variable) vs. IPP, IChl and IPP/IChl ${ }^{\mathrm{a}}$ (independent variables)

\begin{tabular}{|c|c|c|c|}
\hline Seasons & $n$ & $R^{2}$ & Equation $^{\mathrm{b}}$ \\
\hline Winter 1997 & 32 & $\begin{array}{l}0.48 \\
0.36 \\
\text { ns }\end{array}$ & $\begin{array}{l}\log (\text { IBP:IPP })=2.1-0.43( \pm 0.08) \log \text { IPP* } \\
\log (\text { IBP:IPP })=1.6-0.33( \pm 0.05) \log \text { IChl } \\
\log (\text { IBP:IPP }) \text { vs. } \log (\text { IPP } / \text { IChl })\end{array}$ \\
\hline Spring 1998 & 34 & $\begin{array}{l}0.89 \\
0.75 \\
\text { ns }\end{array}$ & $\begin{array}{l}\log (\text { IBP:IPP })=3.5-0.93( \pm 0.06) \log \text { IPP } \\
\log (\text { IBP:IPP })=2.3-0.80( \pm 0.05) \log \text { IChl }^{* *} \\
\log (\text { IBP:IPP }) \text { vs. } \log (\text { IPP } / \text { IChl })\end{array}$ \\
\hline Summer 1998 & 32 & $\begin{array}{l}0.56 \\
0.48 \\
0.41\end{array}$ & $\begin{array}{l}\log (\text { IBP:IPP })=2.6-0.57( \pm 0.09) \log \text { IPP }^{*} \\
\log (\text { IBP:IPP })=2.4-0.84( \pm 0.06) \log \text { IChl }{ }^{* *} \\
\log (\text { IBP:IPP })=4.6-0.73( \pm 0.05) \log (\text { IPP } / \text { IChl })\end{array}$ \\
\hline Autumn 1998 & 34 & $\begin{array}{l}0.66 \\
0.59 \\
\text { ns }\end{array}$ & $\begin{array}{l}\log (\text { IBP:IPP })=2.3-0.48( \pm 0.06) \log \text { IPP* } \\
\log (\text { IBP:IPP })=1.8-0.46( \pm 0.04) \log \text { IChl } \\
\log (\text { IBP:IPP) vs. } \log (\text { IPP } / \text { IChl })\end{array}$ \\
\hline Normal summer, 1994 and 1996 & 12 & $\begin{array}{l}0.64 \\
0.41 \\
\text { ns }\end{array}$ & $\begin{array}{l}\log (\text { IBP:IPP })=7.7-0.88( \pm 0.09) \log \text { IPP } \\
\log (\text { IBP:IPP })=5.3-0.59( \pm 0.08) \log \text { IChl } \\
\log (\text { IBP:IPP) vs. } \log (\text { IPP } / \text { IChl })\end{array}$ \\
\hline Typhoon summer 1996 & 8 & $\begin{array}{l}0.97 \\
0.71 \\
0.59\end{array}$ & $\begin{array}{l}\log (\text { IBP:IPP })=11.8-1.32( \pm 0.08) \log \text { IPP } \\
\log (\text { IBP:IPP })=8.5-1.75( \pm 0.09) \log \text { IChl } \\
\log (\text { IBP:IPP })=9.6-1.80( \pm 0.15) \log (\text { IPP } / \text { IChl })\end{array}$ \\
\hline
\end{tabular}

$R^{2}$, coefficient of determination; $n$, sampling size.

$*$ and $* *$ not significantly different from each other at $p=0.01$ (ANCOVA) and data derived from the Taiwan Strait (Shiah et al., 2000c).

${ }^{\text {a }}$ See Table 1 for abbreviations.

${ }^{\mathrm{b}}$ All significant at $p=0.001$.

was high and varied over a wider range, such as the cases of Lochte et al. (1997), Conan's et al. (1999) studies and our summer data. In the oligotrophic Taiwan Strait, Shiah et al. (2000b) showed that IBP and IPP increased at least 2-fold after the passage of a typhoon (tropical cyclone). In a normal summer, IPP/IChl were low with a range of $4-9 \mathrm{~g} \mathrm{Cg} \mathrm{Chl}^{-1} \mathrm{~d}^{-1}$, IBP:IPP ratio was negatively correlated with IChl only; after the typhoon, IPP/IChl increased up to $21-52 \mathrm{~g} \mathrm{Cg}$ $\mathrm{Chl}^{-1} \mathrm{~d}^{-1}$ and IBP:IPP ratio was negatively correlated with IChl and IPP/IChl concomitantly (Table 3, Fig. 7C). This gave extra support for our speculation stating that the variation of IBP:IPP ratio seemed to be dominated by algal biomass all seasons, while the algal turnover rate effect might occur only when IPP/IChl became high and varied over a wider range. The key point here is that high
IPP could have result from either high algal turnover rate or high algal biomass or both, and its net impact leads to a lower IBP:IPP ratio and thus, a higher magnitude of organic carbon export.

\subsection{Bacterial role in carbon cycling}

Organic carbon can be exported out of the system in dissolved and particulate phases (DOC \& POC). In addition to physical processes, BCD plays a crucial role in determining the amount of leftover DOC that can be exported (Carlson et al., 1994; Hansell and Carlson, 1998). BCD can be calculated by $\mathrm{BP}$ if the growth efficiency (BGE) is known. That is, $\mathrm{BCD}=\mathrm{BP} / \mathrm{BGE}$. To evaluate the potential role bacteria play in carbon cycling could be very difficult if thymidine and carbon conversion factors (TCF and $\mathrm{CCF}$ ) as well as BGE are 
not determined experimentally. The TCF and CCF are for converting bacterial thymidine incorporation rate and bacterial abundance into carbon units, but together they might vary more than 100-fold (Ducklow and Carlson, 1992). Furthermore, BGE also can vary over a wider range of 3-85\% in marine systems (Roland and Cole, 1999, and citations therein), and this can result in a great uncertainty for converting BP to BCD.

For IBP, we compared the IBP:IPP ratio of the ECS shelf with the global average. Ducklow (1999) suggested that the global average of IBP:IPP ratio should not exceed $25 \%$, while the grand average of IBP:IPP ratio of the ECS shelf was $17 \pm 13 \%$. This indicated that the conversion factors used in this study might not be unreasonable.

We used two recently published approaches to calculate BCD values. In revising the Pirt model (Pirt, 1982), Cajal-Medrano and Maske (1999) found that bacterial specific respiration rate (BSR, $\mathrm{d}^{-1}$ ) was positively correlated with $\mathrm{B} \mu$, with an equation of $[\mathrm{BSR}=1.137+0.96 \times \mathrm{B} \mu]$. $\mathrm{BCD}$ then can be calculated as the product of BSR and IBB. The grand averages of $\mathrm{B} \mu$ and IBB were $0.135 \mathrm{~d}^{-1}$ and $337 \mathrm{mg} \mathrm{C} \mathrm{m}^{-2}$, respectively (Table 1); this yielded a $\mathrm{BCD}$ value of $430 \mathrm{mg} \mathrm{C} \mathrm{m}^{-2} \mathrm{~d}^{-1}$. Note that this method does not need BGE in calculation. The other method was proposed by Roland and Cole (1999), claiming that BGE could be derived from $\mathrm{BP}$ with a rectilinear hyperbolas equation, $\quad[\mathrm{BGE}=0.10+0.68 \quad \mathrm{BP} /(5.21+\mathrm{BP})]$, where $\mathrm{BP}$ was in unit of $\mathrm{mg}^{-1} \mathrm{~h}^{-1}$. Then BCD could be calculated as $\mathrm{BP} / \mathrm{BGE}$. This method yielded a $\mathrm{BCD}$ value of $482 \mathrm{mg} \mathrm{C} \mathrm{m}^{-2} \mathrm{~d}^{-1}$ that was very similar to the estimate from the CajalMedrano and Maske (1999) method. The calculated BCD values (430 and $482 \mathrm{mg} \mathrm{C} \mathrm{m}^{-2} \mathrm{~d}^{-1}$ ) were very close to the annual average of IPP (370 $\mathrm{mg} \mathrm{C} \mathrm{m}^{-2} \mathrm{~d}^{-1}$, Table 1), indicating that bacteria might consume organic carbon equivalent to particulate organic carbon production plus algal exudation rate $\left(52 \mathrm{mg} \mathrm{C} \mathrm{m}^{-2} \mathrm{~d}^{-1}\right.$, see below) on an annual scale. This finding agrees with the conclusion derived from a previous study conducted in the southern ECS (Shiah et al., 2000a).

On average, direct release of DOC from phytoplankton exudation $\left(\mathrm{DOC}_{\text {exud }}\right)$ is about
10-14\% of IPP (Ducklow and Carlson, 1992, and citations therein). Given a value of $14 \%$, the grand average of $\mathrm{DOC}_{\text {exud }}$ in the ECS was $52 \mathrm{mg}$ $\mathrm{C} \mathrm{m}^{-2} \mathrm{~d}^{-1}$, which accounted ca. $10 \%$ of the BCD (430-482 $\mathrm{mg} \mathrm{C} \mathrm{m}^{-2} \mathrm{~d}^{-1}$ ). This indicated that DOC from non-phytoplankton sources should be very important in supporting BCD in the ECS. In areas remote from the coast, the non-algal DOC might come from autochthonous sources including sloppy feeding, excretion from other plankton (flagellates and ciliates), dissolution of particulate organic matter and viral lysis (see Fuhrman, 1992, for review). In near-shore areas, in addition to the processes mentioned above, allochthonous sources from river input and sediment resuspension also might play roles in supporting BCD. Unfortunately, like many other bacterial studies, it is almost impossible for us to quantify all of the potential DOC sources.

In summary, this study is probably one of the few that systematically synthesize the possible mechanisms affecting $\mathrm{BP}$ and turnover rate in the ECS shelf. Our results demonstrate that temperature and substrate supply are both important in determining the seasonal and spatial patterns of bacterial rate parameters. For the outer shelf, substrate supply appears to be the primary factor limiting bacterial growth all year round. Inside the middle shelf, bacterial growth seems to be limited by substrate supply in the warm season and temperature in the cold season. From organic carbon cycling point of view, high IBP:IPP ratios recorded in low productivity areas (or periods) may lead to a consequence that there may be less material available for export to the deep ocean and sediments (Conan et al., 1999). The variation of IBP:IPP ratio on IPP in the ECS shelf seems to be more related with the changes of algal biomass during all seasons while the relationship between algal turnover rate and IBP:IPP ratio also becomes significant when algal turnover rate is high and varies over a very wide range, such as the case of the summer data. Estimated annual BCD ( $\sim 430 \mathrm{mg} \mathrm{C} \mathrm{m}^{-2} \mathrm{~d}^{-1}$ ) was approximately equivalent to annual particulate $P P$ rate $(370 \mathrm{mg}$ $\left.\mathrm{C} \mathrm{m}^{-2} \mathrm{~d}^{-1}\right)$. This implies that non-algal organic substrate sources are important for bacterial growth in the ECS shelf. 


\section{Acknowledgements}

Support for F.K. Shiah, G.C. Gong and C.C. Chen was provided by the National Science Council, Taiwan. Cruise assistance from the crew of $\mathrm{R} / \mathrm{V}$ Ocean researcher $I$ is deeply appreciated. This is NCOR Contribution No. 64.

\section{References}

Autio, R.M., 1992. Temperature regulation of brackish water bacterioplankton. Archiv fuer Hydrobiologie, Beihefte 37, 253-263.

Azam, F., Fenchel, T., Field, J.G., Gray, J.S., Meyer-Reil, L.A., Thingstad, F., 1983. The ecological role of watercolumn microbes in the sea. Marine Ecology Progress Series $10,257-263$.

Berman, T., Hoppe, H., Gocke, K., 1994. Response of aquatic bacterial populations to substrate enrichment. Marine Ecology Progress Series 104, 173-184.

Biscaye, P.E., Flagg, C.N., Falkowski, P.G., 1994. The shelfedge exchanges processes experiment, SEEP-II: an introduction to hypotheses, results and conclusions. Deep-Sea Research Part II 41 (2/3), 231-252.

Bott, T.L., 1975. Bacterial growth rates and temperature optima in a stream with a fluctuating thermal regime. Limnology and Oceanogrraphy 20 (2), 191-197.

Cajal-Medrano, R., Maske, H., 1999. Growth efficiency, growth rate and remineralization of organic substrate by bacterioplankton-revising the Pirt model. Aquatic Microbial Ecology 19, 119-128.

Carlson, C.A., Ducklow, H.W., Michaels, A.F., 1994. Annual flux of dissolved organic carbon from the euphotic zone in the northwestern Sargasso Sea. Nature 371 (29), 405-408.

Cole, J.J., Findlay, S., Pace, M.L., 1988. Bacterial production in fresh and saltwater ecosystems: a cross-system overview. Marine Ecology Progress Series 43, 1-10.

Conan, P., Turley, C.T., Stutt, E., Pujo-Pay,, M., Wambeke, F.V., 1999. Relationship between phytoplankton efficiency and the proportion of bacterial production to primary production in the Mediterranean Sea. Aquatic Microbial Ecology 17, 131-144.

Del Giorgio, P.A., Cole, J.J., Cimblerist, A., 1997. Respiration rates in bacteria exceed phytoplankton production in unproductive aquatic systems. Nature 385 (9), $148-151$.

Ducklow, H.W., 1992. Factors regulating bottom-up control of bacteria biomass in open ocean plankton communities. Archiv fuer Hydrobiologie, Beihefte 37, 207-217.

Ducklow, H.W., 1999. The bacterial content of the ocean euphotic zone. FEMS Microbial Ecology 30, 1-10.

Ducklow, H.W., Carlson, C.A., 1992. Oceanic bacterial production. In: Marshall, K.C. (Ed.), Advance in Microbial Ecology. Plenum, New York, pp. 113-181.
Findlay, S., Pace, M.L., Lints, D., Cole, J.J., 1991. Weak coupling of bacterial and algal production in a heterotrophic ecosystem: the Hudson river estuary. Limnology and Oceanography 36 (2), 268-278.

Fuhrman, J.A., 1992. Bacterioplankton roles in cycling of organic matter: the microbial food web. In: Falkowski, P.G., Woodhead, A.D. (Eds.), Primary Productivity and Biogeochemical Cycles in the Sea. Plenum, New York, pp. 361-383.

Fuhrman, J.A., Azam, F., 1982. Thymidine incorporation as a measurement of heterotrophic bacterioplankton production in marine surface waters: evaluation and field results. Marine Biology 66, 109-120.

Gong, G.-C., Wen, Y.-H., Wang, B.-W., Liu, G.-J., 2003. Seasonal variation of chlorophyll $a$ concentration, primary production and environmental conditions in the subtropical East China Sea. Deep-Sea Research II, this issue

Gong, G.C., Shiah, F.K., Liu, K.K., Chuang, W.S., Chang, J., 1996. Effect of Kuroshio intrusion on the chlorophyll distribution in the Southern East China Sea north of Taiwan during spring 1993. Continental Shelf Research 17 (1), 79-94.

Gong, G.C., Shiah, F.K., Liu, K.K., Wen, Y.H., Liang, M.H., 2000. Spatial and temporal variation of chlorophyll $a$, primary productivity and chemical hydrography in the Southern East China Sea. Continental Shelf Research 20 (4-5), 411-436.

Hansell, D.A., Carlson, C.A., 1998. Net community production of dissolved organic carbon. Global Biogeochemical Cycles 12 (3), 443-453.

Hobbie, J.E., Daley, R.J., Jasper, S., 1977. Use of nuclepore filters for counting bacteria by fluorescence microscopy. Apply Environmental Microbiology 33 (5), 1225-1228.

Hoch, M.P., Kirchman, D.L., 1993. Seasonal and inter-annual variability in bacterial production and biomass in a temperate estuary. Marine Ecology Progress Series 98, 283-295.

Hollibaugh, J.T., 1979. Metabolic adaptation in natural bacterial populations supplemented with selected amino acids. Estuarine Coastal and Shelf Science 9, 215-230.

Kirchman, D.L., Keil, R.G., Simon, M., Welschmeyers, N.A., 1993. Biomass and production of heterotrophic bacterioplankton in the oceanic subarctic Pacific. Deep-Sea Research I 40 (5), 967-988.

Lancelot, C., Billen, G., 1984. Activity of heterotrophic bacteria and its coupling to primary production during the spring phytoplankton bloom in the south bight of the North Sea. Limnology and Oceanography 29 (4), $721-730$

Lochte, K., Bjonrsen, P.K., Giesenhagen, H., Weber, A., 1997. Bacterial standing stock and production and their relationship to phytoplankton in the Southern Ocean. Deep-Sea Research Part II 44 (1/2), 321-340.

Parsons, T.R., Maita, Y., Lalli, C.M., 1984. A Manual of Chemical and Biological Methods for Seawater Analysis. Pergamon, New York. 173pp. 
Pirt, S.J., 1982. Maintenance energy: a general model for energy-limited and energy sufficient growth. Archives of Microbiology 133, 300-302.

Pomeroy, L.R., 1974. The ocean's foodweb, a changing paradigm. BioScience 24 (7), 499-504.

Roland, F., Cole, J.J., 1999. Regulation of bacterial growth efficiency in a large turbid estuary. Aquatic Microbial Ecology 20, 31-38.

Sanders, R.W., Caron, D.A., Berninger, U., 1992. Relationships between bacteria and heterotrophic nanoplankton in marine and fresh waters: an inter-ecosystem comparison. Marine Ecology Progress Series 86, 1-14.

Shiah, F.K., Gong, G.C., Liu, K.K., 1999. Temperature vs. substrate limitation of heterotrophic bacterioplankton production across trophic and temperature gradient in the East China Sea. Aquatic Microbial Ecology 17 (3), 247-254.

Shiah, F.K., Liu, K.K., Kao, S.J., Gong, G.C., 2000a. The coupling of bacterial production and hydrography in the southern East China Sea. Continental Shelf Research Part II 20 (4-5), 459-477.

Shiah, F.K., Chung, S.W., Kao, S.J., Gong, G.C., Liu, K.K., 2000b. Biological and hydrographical responses to tropical cyclones (typhoons) in the continental shelf of the Taiwan Strait. Continental Shelf Research 20, 1-16.

Shiah, F.K., Gong, G.C., Chen, T.Y., Chen, C.C., 2000c. Temperature dependence of bacterial specific growth rates on the continental shelf of the East China Sea and its potential application of using SST to estimate bacterial production. Aquatic Microbial Ecology 22 (2), $155-162$

Shiah, F.K., Chen, T.Y., Gong, G.C., Chen, C.C., Chiang, K.P., Hung, J.J., 2001. Differential coupling of bacterial and primary production in mesotrophic and oligotrophic systems of the East China Sea. Aquatic Microbial Ecology 23 (3), 273-282.

Smith, S.V, Hollibaugh, J.T., 1993. Coastal metabolism and the oceanic organic carbon balance. Review Geophysics 31 (1), 75-89.

White, P.A., Kalff, J., Rasmussen, J.B., Gasol, J.M., 1991. The effects of temperature and algal biomass on bacterial production and specific growth rate in freshwater and marine habitats. Microbial Ecology 21, 99-118.

Wiebe, W.J., Sheldon, W.M., Pomeroy, L.R., 1992. Bacterial growth in the cold: evidence for an enhanced substrate requirement. Apply Environmental Microbiology 58 (1), 359-364.

Wiebe, W.J., Sheldon, W.M., Pomeroy, L.R., 1993. Evidence for enhanced substrate requirement by marine mesophilic bacterial isolates at minimal temperatures. Microbial Ecology 25, 151-159.

Williams, P.J.L., 1981. Incorporation of microheterotrophic processes into the classical paradigm of the planktonic food web. Kieler Meeresforsch 5, 1-28.

Wong, G.T.F., Chao, S.Y., Li, Y.H., Shaih, F.K., 2000. The Kuroshio edge exchange processes (KEEP) study - an introduction to hypotheses and highlights. Continental Shelf Research Part 20 (4-5), 335-348. 